\title{
Global consensus on nutritional rickets: Implications for Australia
}

\author{
Siafarikas, Aris ${ }^{1,2,3}$; Simm, Peter ${ }^{5,6,7}$; Zacharin, Margaret ${ }^{5,6,7}$; Jefferies, Craig ${ }^{8,9}$; Lafferty, \\ Antony R. ${ }^{10,11}$; Wheeler, Benjamin $\mathrm{J}^{12}$, Tham, Elaine ${ }^{13}$; Brown, Justin ${ }^{14,26}$; Biggin, \\ Andrew $^{15,16}$; Hofman, Paul9; Woodhead, Helen ${ }^{17,18,19}$; Rodda, Christine ${ }^{7,20,21}$ Jensen, \\ Diane 22,23 ; Brookes, Denise ${ }^{24}$; Munns, Craig F ${ }^{15,25}$ (APEG Bone and Mineral Working \\ Group)
}

1. Department of Endocrinology and Diabetes, Perth Children's Hospital, Perth, Western Australia, Australia

2. Telethon Kids Institute for Child Health Research and Division of Paediatrics, Medical School, University of Western Australia, Australia

3. Institute for Health Research, University of Notre Dame, Fremantle, Western Australia, Australia

4. Edith Cowan University, Exercise Medicine Research Institute, Joondalup, Western Australia, Australia

5. Department of Endocrinology and Diabetes, Royal Children's Hospital, Melbourne, Victoria, Australia

6. Murdoch Childrens Research Institute, Department of Paediatrics, University of Melbourne, Victoria, Australia

7. Dept of Paediatrics, University of Melbourne

8. Starship Children's Health, Auckland, New Zealand

9. Liggins Institute, University of Auckland, Auckland, New Zealand

10. Department of Paediatrics, Canberra Hospital, ACT, Australia

11. Paediatrics and Child Health, ANU Medical School, Canberra, ACT Australia

12. Department of Women's and Children's Health, University of Otago, Dunedin, New Zealand

13. Women's and Children's Hospital, Adelaide, SA

14. Department of Paediatrics, Monash University, Melbourne, Victoria, Australia

15. Institute of Endocrinology \& Diabetes, Children's Hospital Westmead, Sydney, Australia

16. Discipline of Child \& Adolescent Health, University of Sydney, Sydney, Australia

17. Sydney Children's Hospital, Randwick, Sydney

18. Royal North Shore Hospital, St Leonards, Sydney

19. School of Women's and Children's Health, University of NSW

20. North West Academic Centre, AIMSS, The University of Melbourne, Melbourne, Victoria, Australia

21. Western Centre for Health Research and Education Western Health Sunshine Hospital, St Albans, Victoria, Australia

22. Children's Health Queensland, Hospital and Health Services District, South Brisbane, Queensland, Australia

23. Centre for Children's Health Research, University of Queensland, South Brisbane, Queensland, Australia

24. QUT Centre for Children's Health Research, Level 6, 62 Graham Street, South Brisbane 4101

25. Discipline of Paediatrics and Child Health, University of Sydney, Sydney, Australia

26. Department of Paediatric Endocrinology and Diabetes, Monash Childrens Hospital, Melbourne, Victoria, Australia

\section{Position Paper}

Wordcount: 2,495

4 tables

The group has no conflicts of interest to declare

\section{Corresponding Author:}

This is the author manuscript accepted for publication and has undergone full peer review but has not been through the copyediting, typesetting, pagination and proofreading process, which may lead to differences between this version and the Version of Record. Please cite this article as doi: 10.1111/jpc.14941 


\section{Clinical Associate Professor Aris Siafarikas MD FRACP}

Perth Children's Hospital, Department of Endocrinology and Diabetes

15 Hospital Avenue

Nedlands, WA 6009, Australia

Tel: +61 86456 1111, email: Aris.Siafarikas@health.wa.gov.au

\section{Introduction}

In 2016, an international group of specialists from various disciplines was supported by their respective professional societies to develop a global consensus for prevention, diagnosis and management of nutritional rickets. Given that nutritional rickets is a preventable disorder with potentially life-long or fatal sequelae, the group advocated for the "eradication of nutritional rickets and osteomalacia", through vitamin D supplementation of all infants, pregnant women, and individuals from high-risk groups and the implementation of international food fortification programs to ensure nutritional sufficiency of vitamin $D$ and calcium for the whole population ${ }^{1}$. The current Australian and New Zealand (ANZ) position statement for pregnant women, infants, children and adolescents (2013) $)^{2}$ accompanies a position statement for adults (2012) . $^{3}$ Both statements were commissioned by the Australian and New Zealand Bone and Mineral Society (ANZBMS) to be prepared by multidisciplinary teams of experts in areas including adult and paediatric endocrinology, nutrition, exercise, measurement, obstetrics and sun exposure. With support of the council of the Australasian Paediatric Endocrine Group (APEG), members of the APEG Bone and Mineral Working Group have reviewed the global consensus document and summarised key areas highlighting differences focusing on the ANZ paediatric statement to provide a guide for interpretation and clinical practice.

\section{Assessment of strength of recommendations and level of evidence}

Recommendations of the global consensus statement were evaluated using the Grading of Recommendations, Assessment, Development and Evaluation 
system (GRADE) ${ }^{4}$ addressing areas of definition, diagnosis, treatment and prevention of nutritional rickets $(N R)^{1}$. The National Health and Medical Research Council (NHMRC) recommends the GRADE system for the development of guidelines ${ }^{5}$. This system uses a combination of numbers to assess the recommendation and symbols for the level of evidence (table 1$)^{4}$. We have added the evaluation of the consensus group in the text.

The 2012 and 2013 Australian and New Zealand (ANZ) position papers ${ }^{2,3}$ were based on literature searches for articles regarding vitamin D dosing in paediatric age groups, during pregnancy/ lactation and in adults. The level of evidence was described following the NHMRC grading (table 1$)^{5}$. Initial evidence-based statements were circulated amongst senior colleagues and members of respective professional societies that included the Australian and New Zealand Bone Mineral Society (ANZBMS), Endocrine Society of Australia (ESA) and APEG. Revisions were incorporated with consensus from the authoring working group.

\section{Definition and diagnosis of Nutritional Rickets}

Nutritional rickets (NR) is a childhood condition characterized by impaired mineralisation of the growth plate and osteoid mainly affecting infants and toddlers $^{1}$. The global consensus puts emphasis on both calcium and vitamin D deficiency as factors contributing to the pathophysiology of NR. NR is usually seen in children who have both 25-hydroxy vitamin D (25OHD) and nutritional calcium deficiency. Severe deficiency in either vitamin D or dietary calcium alone can also result in nutritional rickets ${ }^{6}$. Insufficiency of either vitamin D or calcium and combinations of normal $250 \mathrm{HD}$ and deficient calcium levels and vice versa are clinically asymptomatic ${ }^{6}$.

Nutritional rickets should be diagnosed on the basis of history, physical examination, biochemical testing and confirmed by radiographs $(1+++, A)^{1}$. Individuals with nutritional rickets may have a history of poor calcium and/or vitamin $\mathrm{D}$ intake. Maternal vitamin $\mathrm{D}$ deficiency can be a contributing factor in 
infants $^{1,2}$. Osseous clinical signs include widened epiphyses of wrists and ankles, leg deformities, craniotabes, rachitic rosary, frontal bossing, delayed closing of the fontanelle as well as delayed tooth eruption. Bone and muscle pain has been described ${ }^{1,2}$. Non osseous features include delayed gross motor development, poor linear growth and less frequently raised intracranial pressure and cardiomyopathy ${ }^{2}$. Once compensatory mechanisms have been exhausted, biochemically NR presents with decreased 25OHD, serum calcium, serum phosphate and urinary calcium; alkaline phosphatase (ALP), parathyroid hormone (PTH) and urinary phosphate are elevated. Typical radiographic findings are splaying and cupping of the metaphyses with coarse trabecular features and signs of osteopenia ${ }^{2}$.

Clarity was also provided on a clinically relevant issue, with the global consensus highlighting that only children with radiographically confirmed rickets have an increased risk of fracture, not children with isolated biochemical $250 H D$ deficiency $(1++O, B)^{1,7}$. The APEG bone and mineral working group recommends following the definition of the global consensus statement.

\section{Interpretation of Vitamin D status}

250HD levels reflect an individual's vitamin D status. There are a variety of assays in use. For the interpretation of results significant intra- and inter-assay variability needs to be considered ${ }^{8}$.

Cutoffs for the interpretation of $250 \mathrm{HD}$ results are described in table 2 . The APEG working groups agrees with both statements in that more data are required to determine whether higher levels of $250 \mathrm{HD}$ (i.e.: a cut-off $75 \mathrm{nmol} / \mathrm{L}$ ) are needed to cover potential non-skeletal functions of vitamin D.

The global consensus does not recommend routine $250 \mathrm{HD}$ screening in healthy children $(1+++, A)$, but rather universal supplementation of all infants $<12$ months of age and supplementation of children at risk of vitamin D deficiency $^{1}$. Targeted screening and supplementation are currently recommended in Australia if risk factors for vitamin D deficiency are present ${ }^{2,3}$.

This article is protected by copyright. All rights reserved. 
These risk factors include lack of sun exposure (UVB), highly pigmented skin, veiling, hospitalisation, obesity, chronic illness such as liver and renal disease, fat malabsorption (in cystic fibrosis, coeliac or inflammatory bowel disease). Risk factors specific to infants are maternal vitamin D deficiency and exclusive breastfeeding $^{2}$. In Australia migrants are at increased risk of vitamin D deficiency ${ }^{9}$. There are no specific recommendations for indigenous Australians. A study from Western Australia revealed higher vitamin D levels for those living in rural areas compared to those living in Metropolitan settings ${ }^{10}$.

The APEG Bone and Mineral Working Group supports the position of the global consensus and recommends to introduce universal supplementation of all infants $<12$ months of age and supplementation of children at risk of vitamin D deficiency in Australia and New Zealand. Screening for vitamin D deficiency should be restricted to populations at risk. There remains no indication for the universal screening of adolescents ${ }^{11}$.

\section{Interpretation of Calcium intake}

It is highlighted that both serum $250 \mathrm{HD}$ level and dietary calcium intake contribute to bone mineralisation. The optimal source of calcium for infants is human milk ${ }^{12}$, cow's milk and dairy products are preferred sources outside of early childhood. Breast milk contains $250 \mathrm{mg}$ of calcium/litre ${ }^{13}$. The bioavailability of calcium from breast milk is higher than from formula and cow's milk. Hence the calcium concentration in infant formulas has been increased. There are no specific recommendations for routine calcium supplementation of breast milk- or formula fed infants ${ }^{12}$, and alterations in maternal calcium intake do not affect the calcium concentration in breast milk ${ }^{13}$. Recommendations vary between guidelines looking at groups 0-6 months and $>1$ year of age (table $3)^{2,14}$. The APEG working group supports the higher recommendations for each respective group.

\section{Risk factors for vitamin D deficiency}

This article is protected by copyright. All rights reserved. 
Guidelines agree that high-risk groups for vitamin D deficiency include children and adolescents with fat malabsorption, liver disease and renal insufficiency. Special attention is directed to maternal vitamin $D$ deficiency $(1+++, A)^{15}$. Vitamin $D$ deficiency is more prevalent in infants born to a mother with low vitamin $D$ and exclusive breast-feeding combined with at least one other risk factor $^{1,2}$. Strong evidence is provided for the important role of UVB $(1+++, A)$. Maternal and infant/ childhood risk factors include full body clothing cover, dark skin pigmentation or restricted sun (UVB) exposure $(1+++, A)^{16,17}$. It is pointed out in the global statement that no safe threshold of UV exposure allows for sufficient vitamin D synthesis across the population without increasing skin cancer risk and that there is no firm evidence to provide a recommendation for a specific period of time for "safe" sun exposure $(2++\mathrm{O}, \mathrm{C})$.

The APEG bone and mineral working group follows the criteria describing groups at risk of vitamin D deficiency. For guidance regarding safe sun exposure we refer to the recommendation of the Australian Cancer Council.

\section{Pregnancy and lactation}

According to the global consensus the relationship between vitamin $D$ during pregnancy, infant growth and bone mass, is graded as weak, with moderate evidence $^{18-20}$. There is however an undeniable association between maternal vitamin $\mathrm{D}$ at delivery and that of the newborn. It is concluded therefore, that all pregnant women should be given supplementation with vitamin D at $600 \mathrm{lU} / \mathrm{d}$, without having evidence from RCTs $(2++\mathrm{O}, \mathrm{C})^{21}$. Lactating women should meet the dietary recommendations for vitamin $D$ of $600 \mathrm{IU} / \mathrm{d}(1+++, A)^{22-25}$ without taking extra vitamin $D$ to supplement their infant $(2++O, C)$. The approach from the ANZ statement suggests dosing vitamin D supplementation during pregnancy and lactation based on 25OHD levels ${ }^{2}$. Recent local data has posed some concerns with this approach and the APEG bone and mineral working group supports universal supplementation of pregnant women ${ }^{26}$.

The global consensus document ${ }^{1}$ states that pregnant women do not need 
calcium intakes above recommended non-pregnant intakes $(1+++, A)^{27-29}$ and that maternal calcium intake during pregnancy or lactation is not associated with breast milk calcium concentrations $(1+++, A)^{30}$. The ANZ statement recommends a calcium intake of $1300 \mathrm{mg} /$ day for 14-18 year old and 1000 mg/day for 19-50 year old pregnant and lactating women².

The APEG Bone and Mineral Working Group supports that all pregnant women should be given supplementation with vitamin $\mathrm{D}$ at $600 \mathrm{IU} / \mathrm{d}$ and is of the opinion that this area needs further study and discussion amongst specialist societies in Australia to reach consensus on the issue of universal supplementation (global consensus document) and targeted supplementation (ANZ position paper).

\section{Supplementation with vitamin D}

Recommendations are for use of oral vitamin D2 or D3 as daily and intermittent vitamin D3 high-dose therapy (also called "stoss therapy"). Stoss therapy has not been recommended for infants $<3$ months of age $(1+++, A)^{31,32}$ (table 4). Clinically groups that can benefit from stoss therapy are those older than 3 months at risk of non-adherence. Intramuscular treatment is a therapeutic option for patients with malabsorption. Oral calcium supplementation (500 $\mathrm{mg} /$ day) should be routinely used in conjunction with vitamin $D$ regardless of age or weight for the treatment of NR $(1+++, A)^{33,34}$.

Current Australian recommendations are specified according to 250HD levels and not predicated on the treatment of NR (table 4). The ANZ statement for infants, children and adolescents ${ }^{2}$ provides specific dosing schedules for groups with vitamin D insufficiency (25OHD 30-49 nmol/L) that are at risk of vitamin D deficiency (table 4). Any treatment of nutritional rickets needs to be followed by maintenance supplementation with vitamin $D$.

The APEG Bone and Mineral Working Group endorses the dosing schedule for nutritional rickets as suggested by the global consensus guidelines. However, we point out that further studies are needed to clarify dosing for preterm infants.

This article is protected by copyright. All rights reserved. 
Use in combination with ANZ guidelines is recommended to provide guidance for the treatment of vitamin D insufficiency.

Based on clinical events in Australia we raise concerns and a warning against self-medication with high doses of vitamin D obtained through the internet. These medications can cause vitamin $D$ intoxication if not administered under medical supervision ${ }^{35,36}$.

\section{Public Health strategies}

Within the general paediatric population there are data suggesting an increase in the incidence of vitamin D deficiency ${ }^{26,37,38}$. For adults the Australian Health Survey ${ }^{39}$ showed vitamin D deficiency in 31\% of 18-34 year olds, $15 \%$ of $65-74$ year olds and $20 \%$ in those aged 75 years and older. Fifteen percent of 12-17 year olds were deficient with similar rates for males and females. There were no data for younger age groups. A study of the Australian Paediatric Surveillance Unit (APSU) revealed an incidence for vitamin D deficiency rickets of 4.9:100,000 in children with a median age of 6.3 years (range 0.2-15 years). Most children had dark or intermediate skin colour and were from Africa with a refugee background ${ }^{9}$. In New Zealand the incidence of rickets in children aged $<15$ years was $2.2 / 100,000(95 \% \mathrm{Cl} 1.4-3.5)$; in those $<3$ years $10.5 / 100,000$ $(95 \% \mathrm{Cl} 6.7-16.6)^{40}$. Internationally, nutritional rickets is a significant health problem in Asia, Africa and the Middle East ${ }^{37}$.

Establishing public health strategies to "eradicate rickets" is a very strong component of the global guidelines. Nutritional rickets, osteomalacia, and vitamin $\mathrm{D}$ and calcium deficiencies are characterized as preventable global public health problems in infants, children, and adolescents $(1+++, A)$. Recommendations are made against population-based screening with serum $250 H D$, serum alkaline phosphatase, or radiographs $(1+++, A)^{41,42}$. Instead, screening for nutritional rickets should be based on clinical features, followed by radiographic confirmation of suspected cases $(1+++, A)^{41,42}$.

This article is protected by copyright. All rights reserved. 
Suggested public health strategies for rickets prevention include universal supplementation $(1+++, A)^{43}$ with vitamin $D$ supplements being incorporated into childhood primary health care programs and antenatal care programs.

A study from Turkey demonstrated that the incidence of rickets could be reduced through universal vitamin $D$ supplementation and public health initiatives as advocated in most European countries ${ }^{37,44}$. Doses recommended by the global consensus for universal vitamin D supplementation are 400 IU/day (10 mcg/day) for all infants from birth to 12 months of age $(1+++, A)^{21}$. Only individuals with risk factors should receive $600 \mathrm{IU} / \mathrm{d}$ (15 mcg/day) thereafter, independent of the mode of feeding $(1+++, A)^{21}$. Rickets prevention programs should be implemented in populations with a high prevalence of vitamin $D$ deficiency or limited vitamin D and/or calcium intakes and in groups of infants and children at risk of rickets $(1+++, A)^{43}$. This is different to the paediatric ANZ position statement that recommended prevention with 200 IU/day for preterm infants and $400 \mathrm{IU} /$ day for age groups from <3 month old term infants to 18 years only in populations with risk factors.

Furthermore it is suggested by the global consensus to fortify staple foods with vitamin D and calcium, as appropriate, based on dietary patterns, because food fortification has been shown to increase $250 \mathrm{HD}$ levels and dietary calcium intake sufficiently to prevent rickets in infants, children and adolescents (1+++, A) ${ }^{45,46}$. In Australia and New Zealand there is experience with food fortification from the addition of iodine and folic acid to bread (Food Standards Australia New Zealand, www.foodstandards.gov.au).

There is a need for health economic models to analyse the cost-effectiveness of supplementation strategies and food fortification programs for vitamin $D$ to be initiated in Australia. To our knowledge a campaign for universal vitamin $D$ supplementation has not been started in Australia or New Zealand. North American and European countries have extensive experience with programs for universal vitamin D supplementation. A public health strategy combining 
universal vitamin D supplementation and health education in an ethnic minority at risk of vitamin D deficiency was described in Birmingham, United Kingdom ${ }^{47}$. An example of and analysis of a prevention program looking at older adults has been provided by Lee et al. (2013) ${ }^{48}$. Factors for analysis include medication cost, quality of life and health benefit ${ }^{48}$. An internet search (Search question: "vitamin D suspension Australia") revealed that over the counter vitamin D supplements cost approximately AU\$ 0.22 for $400 \mathrm{IU} /$ day. Data on the impact on quality of life and health benefit were not available.

In principal the APEG Bone and Mineral Working Group supports the goal of promoting efforts to address the public health impact of nutritional rickets as both a clinical and a public health issue.

We conclude that updated global recommendations for therapy of nutritional rickets complement previously published position statements for Australia and New Zealand. Screening, universal vitamin D supplementation, management and the implementation of public health strategies need to be further explored for Australia.

\section{Competing interests statement}

Competing interests: No relevant disclosures.

This article is protected by copyright. All rights reserved. 


\section{References}

1. Munns CF, Shaw N, Kiely M, et al. Global Consensus Recommendations on Prevention and Management of Nutritional Rickets. J Clin Endocrinol Metab 2016;101:394-415.

2. Paxton GA, Teale GR, Nowson CA, et al. Vitamin D and health in pregnancy, infants, children and adolescents in Australia and New Zealand: a position statement. Med J Aust 2013;198:142-3.

3. Nowson CA, McGrath JJ, Ebeling PR, et al. Vitamin D and health in adults in Australia and New Zealand: a position statement. Med $\mathrm{J}$ Aust 2012;196:686-7.

4. Swiglo BA, Murad $\mathrm{MH}$, Schunemann $\mathrm{HJ}$, et al. A case for clarity, consistency, and helpfulness: state-of-the-art clinical practice guidelines in endocrinology using the grading of recommendations, assessment, development, and evaluation system. J Clin Endocrinol Metab 2008;93:666-73. 5. NHMRC. Procedures and requirements for meeting the 2011 NHMRC standard for clinical practice guidelines - Summary for developers. National Health and Medical Research Council 2011.

6. Hogler W. Complications of vitamin D deficiency from the foetus to the infant: One cause, one prevention, but who's responsibility? Best Pract Res Clin Endocrinol Metab 2015;29:385-98.

7. Chapman T, Sugar N, Done S, Marasigan J, Wambold N, Feldman K. Fractures in infants and toddlers with rickets. Pediatr Radiol 2010;40:1184-9.

8. Yates AM, Bowron A, Calton $L$, et al. Interlaboratory variation in 25hydroxyvitamin D2 and 25-hydroxyvitamin D3 is significantly improved if common calibration material is used. Clin Chem 2008;54:2082-4.

9. Munns CF, Simm PJ, Rodda CP, et al. Incidence of vitamin D deficiency rickets among Australian children: an Australian Paediatric Surveillance Unit study. Med J Aust 2012;196:466-8.

10. Tan J, Martin A, Siafarikas A, et al. Vitamin D deficiency in Aboriginal children and adolescents in metropolitan and rural Western Australia. Internal Medicine Journal 2010;40.

11. Soliman AT, De Sanctis V, Elalaily R, Bedair S, Kassem I. Vitamin D deficiency in adolescents. Indian J Endocrinol Metab 2014;18:S9-S16.

12. Baker SS, Cochran WJ, Flores CA, et al. American Academy of Pediatrics. Committee on Nutrition. Calcium requirements of infants, children, and adolescents. Pediatrics 1999;104:1152-7.

13. Kent JC, Arthur PG, Mitoulas LR, Hartmann PE. Why calcium in breastmilk is independent of maternal dietary calcium and vitamin $D$. Breastfeed Rev 2009;17:5-11.

14. Brouwer-Brolsma EM, Bischoff-Ferrari HA, Bouillon R, et al. Vitamin D: do we get enough? A discussion between vitamin $D$ experts in order to make a step towards the harmonisation of dietary reference intakes for vitamin D across Europe. Osteoporos Int 2013;24:1567-77. 
15. Elidrissy AT, Sedrani SH, Lawson DE. Vitamin D deficiency in mothers of rachitic infants. Calcif Tissue Int 1984;36:266-8.

16. Webb AR, Holick MF. The role of sunlight in the cutaneous production of vitamin D3. Annu Rev Nutr 1988;8:375-99.

17. Bogh MK. Vitamin D production after UVB: aspects of UV-related and personal factors. Scand J Clin Lab Invest Suppl 2012;243:24-31.

18. Brooke OG, Brown IR, Bone CD, et al. Vitamin D supplements in pregnant Asian women: effects on calcium status and fetal growth. Br Med J 1980;280:751-4.

19. Kalra $P$, Das V, Agarwal A, et al. Effect of vitamin D supplementation during pregnancy on neonatal mineral homeostasis and anthropometry of the newborn and infant. The British journal of nutrition 2012;108:1052-8.

20. Cockburn F, Belton NR, Purvis RJ, et al. Maternal vitamin D intake and mineral metabolism in mothers and their newborn infants. $\mathrm{Br}$ Med $\mathrm{J}$ 1980;281:11-4.

21. Ross AC, Manson JE, Abrams SA, et al. The 2011 report on dietary reference intakes for calcium and vitamin $D$ from the Institute of Medicine: what clinicians need to know. J Clin Endocrinol Metab 2011;96:53-8.

22. Hollis BW, Wagner CL. Vitamin D requirements during lactation: highdose maternal supplementation as therapy to prevent hypovitaminosis $D$ for both the mother and the nursing infant. Am J Clin Nutr 2004;80:1752S-8S.

23. Wagner CL, Hulsey TC, Fanning D, Ebeling M, Hollis BW. High-dose vitamin D3 supplementation in a cohort of breastfeeding mothers and their infants: a 6-month follow-up pilot study. Breastfeed Med 2006;1:59-70.

24. Saadi HF, Dawodu A, Afandi B, et al. Effect of combined maternal and infant vitamin D supplementation on vitamin D status of exclusively breastfed infants. Maternal \& child nutrition 2009;5:25-32.

25. Oberhelman SS, Meekins ME, Fischer PR, et al. Maternal vitamin D supplementation to improve the vitamin D status of breast-fed infants: a randomized controlled trial. Mayo Clin Proc 2013;88:1378-87.

26. Wheeler BJ, Taylor BJ, de Lange M, et al. A Longitudinal Study of 25Hydroxy Vitamin D and Parathyroid Hormone Status throughout Pregnancy and Exclusive Lactation in New Zealand Mothers and Their Infants at 45 degrees S. Nutrients 2018;10.

27. Jarjou LM, Prentice A, Sawo Y, et al. Randomized, placebo-controlled, calcium supplementation study in pregnant Gambian women: effects on breastmilk calcium concentrations and infant birth weight, growth, and bone mineral accretion in the first year of life. Am J Clin Nutr 2006;83:657-66.

28. Koo WW, Walters JC, Esterlitz J, Levine RJ, Bush AJ, Sibai B. Maternal calcium supplementation and fetal bone mineralization. Obstet Gynecol 1999;94:577-82.

29. Villar J, Abdel-Aleem H, Merialdi M, et al. World Health Organization randomized trial of calcium supplementation among low calcium intake pregnant women. Am J Obstet Gynecol 2006;194:639-49. 
30. Vaughan LA, Weber CW, Kemberling SR. Longitudinal changes in the mineral content of human milk. Am J Clin Nutr 1979;32:2301-6.

31. Markestad T, Halvorsen S, Halvorsen KS, Aksnes L, Aarskog D. Plasma concentrations of vitamin D metabolites before and during treatment of vitamin D deficiency rickets in children. Acta paediatrica Scandinavica 1984;73:225-31. 32. Kruse K. Pathophysiology of calcium metabolism in children with vitamin D-deficiency rickets. J Pediatr 1995;126:736-41.

33. Thacher TD, Fischer PR, Pettifor JM, et al. A comparison of calcium, vitamin $D$, or both for nutritional rickets in Nigerian children. The New England journal of medicine 1999;341:563-8.

34. Balasubramanian K, Rajeswari J, Gulab, et al. Varying role of vitamin D deficiency in the etiology of rickets in young children vs. adolescents in northern India. J Trop Pediatr 2003;49:201-6.

35. Vogiatzi MG, Jacobson-Dickman E, Deboer MD, Drugs, Therapeutics Committee of The Pediatric Endocrine S. Vitamin d supplementation and risk of toxicity in pediatrics: a review of current literature. J Clin Endocrinol Metab 2014;99:1132-41.

36. Zhou L, Taylor-Miller T, Zacharin M, Efron D. Extreme hypercalcaemia due to accidental vitamin D intoxication. J Paediatr Child Health 2019;55:1046.

37. Creo AL, Thacher TD, Pettifor JM, Strand MA, Fischer PR. Nutritional rickets around the world: an update. Paediatr Int Child Health 2017;37:84-98.

38. Bowyer L, Catling-Paull C, Diamond T, Homer C, Davis G, Craig ME. Vitamin D, PTH and calcium levels in pregnant women and their neonates. Clin Endocrinol (Oxf) 2009;70:372-7.

39. Survey AH. Feature Article: Vitamin D. Australian Bureau of Statistics 2014.

40. Wheeler BJ, Dickson NP, Houghton LA, Ward LM, Taylor BJ. Incidence and characteristics of vitamin $D$ deficiency rickets in New Zealand children: a New Zealand Paediatric Surveillance Unit study. Aust N Z J Public Health 2015;39:380-3.

41. Strand MA, Perry J, Jin M, et al. Diagnosis of rickets and reassessment of prevalence among rural children in northern China. Pediatr Int 2007;49:2029.

42. Gordon $\mathrm{CM}$, Williams $\mathrm{AL}$, Feldman $\mathrm{HA}$, et al. Treatment of hypovitaminosis $\mathrm{D}$ in infants and toddlers. $\mathrm{J}$ Clin Endocrinol Metab 2008;93:2716-21.

43. Organization $\mathrm{WH}$. Guidelines on food fortification with micronutrients. Geneva, Switzerland: World Health Organisation; 2006.

44. Siafarikas A, Deichl A, Jahreis G, et al. Cross-sectional analysis of universal vitamin D supplementation in former East Germany during the first year of life. J Pediatr Endocrinol Metab 2017;30:395-404. 
45. Flynn MA, O'Brien CM, Ross V, Flynn CA, Burke SJ. Revision of foodbased dietary guidelines for Ireland, Phase 2: recommendations for healthy eating and affordability. Public health nutrition 2012;15:527-37.

46. Allen LH. New approaches for designing and evaluating food fortification programs. The Journal of nutrition 2006;136:1055-8.

47. Moy RJ, McGee E, Debelle GD, Mather I, Shaw NJ. Successful public health action to reduce the incidence of symptomatic vitamin $\mathrm{D}$ deficiency. Arch Dis Child 2012;97:952-4.

48. Lee $\mathrm{RH}$, Weber T, Colon-Emeric C. Comparison of cost-effectiveness of vitamin $D$ screening with that of universal supplementation in preventing falls in community-dwelling older adults. J Am Geriatr Soc 2013;61:707-14.

This article is protected by copyright. All rights reserved. 


\section{Tables}

Table 1: Grading of Recommendations, Assessment, Development and Evaluation system (GRADE) and National Health and Medical Research Council (NHMRC) levels of evidence

Table 2: $\quad$ Classification of 25OHD status comparing the global consensus guidelines and the ANZ position paper

Table 3: $\quad$ Classification of calcium intake comparing the global consensus guidelines and the ANZ position paper

Table 4: Overview of vitamin $D$ dosage regimens comparing the global consensus guidelines and the ANZ position paper

This article is protected by copyright. All rights reserved. 


\title{
Global consensus on nutritional rickets: Implications for Australia
}

\author{
Siafarikas, Aris ${ }^{1,2,3}$; Simm, Peter ${ }^{5,6,7}$; Zacharin, Margaret ${ }^{5,6,7}$; Jefferies, Craig ${ }^{8,9}$; Lafferty, \\ Antony R. ${ }^{10,11}$; Wheeler, Benjamin $\mathrm{J}^{12}$, Tham, Elaine ${ }^{13}$; Brown, Justin ${ }^{14,26}$; Biggin, \\ Andrew ${ }^{15,16}$; Hofman, Paul'; Woodhead, Helen ${ }^{17,18,19 ;}$; Rodda, Christine ${ }^{7,20,21}$ Jensen, \\ Diane $^{22,23}$; Brookes, Denise ${ }^{24}$; Munns, Craig F ${ }^{15,25}$ (APEG Bone and Mineral Working \\ Group)
}

1. Department of Endocrinology and Diabetes, Perth Children's Hospital, Perth, Western Australia, Australia

2. Telethon Kids Institute for Child Health Research and Division of Paediatrics, Medical School, University of Western Australia, Australia

3. Institute for Health Research, University of Notre Dame, Fremantle, Western Australia, Australia

4. Edith Cowan University, Exercise Medicine Research Institute, Joondalup, Western Australia, Australia

5. Department of Endocrinology and Diabetes, Royal Children's Hospital, Melbourne, Victoria, Australia

6. Murdoch Childrens Research Institute, Department of Paediatrics, University of Melbourne, Victoria, Australia

7. Dept of Paediatrics, University of Melbourne

8. Starship Children's Health, Auckland, New Zealand

9. Liggins Institute, University of Auckland, Auckland, New Zealand

10. Department of Paediatrics, Canberra Hospital, ACT, Australia

11. Paediatrics and Child Health, ANU Medical School, Canberra, ACT Australia

12. Department of Women's and Children's Health, University of Otago, Dunedin, New Zealand

13. Women's and Children's Hospital, Adelaide, SA

14. Department of Paediatrics, Monash University, Melbourne, Victoria, Australia

15. Institute of Endocrinology \& Diabetes, Children's Hospital Westmead, Sydney, Australia

16. Discipline of Child \& Adolescent Health, University of Sydney, Sydney, Australia

17. Sydney Children's Hospital, Randwick, Sydney

18. Royal North Shore Hospital, St Leonards, Sydney

19. School of Women's and Children's Health, University of NSW

20. North West Academic Centre, AIMSS, The University of Melbourne, Melbourne, Victoria, Australia

21. Western Centre for Health Research and Education Western Health Sunshine Hospital, St Albans, Victoria, Australia

22. Children's Health Queensland, Hospital and Health Services District, South Brisbane, Queensland, Australia

23. Centre for Children's Health Research, University of Queensland, South Brisbane, Queensland, Australia

24. QUT Centre for Children's Health Research, Level 6, 62 Graham Street, South Brisbane 4101

25. Discipline of Paediatrics and Child Health, University of Sydney, Sydney, Australia

26. Department of Paediatric Endocrinology and Diabetes, Monash Childrens Hospital, Melbourne, Victoria, Australia

\section{Position Paper}

Wordcount: 2,495

4 tables

The group has no conflicts of interest to declare

\section{Corresponding Author:}

Clinical Associate Professor Aris Siafarikas MD FRACP

Perth Children's Hospital, Department of Endocrinology and Diabetes

\section{Hospital Avenue}

Nedlands, WA 6009, Australia

Tel: +61 86456 1111, email: Aris.Siafarikas@health.wa.gov.au 
Table 1

GRADE System

\begin{tabular}{|c|c|c|}
\hline \multirow{2}{*}{$\begin{array}{l}\text { Recommendation } \\
\text { 1: Strong } \\
\text { Applies to most patients, benefits } \\
\text { outweigh the risk }\end{array}$} & \multicolumn{2}{|l|}{ Level of evidence } \\
\hline & $\begin{array}{l}\text { +++ } \\
\text { High quality }\end{array}$ & $\begin{array}{l}\text { Prospective cohort } \\
\text { studies or } \\
\text { randomised } \\
\text { controlled trials, } \\
\text { RCT, low risk of } \\
\text { bias }\end{array}$ \\
\hline \multirow[t]{2}{*}{$\begin{array}{l}\text { 2: Weak } \\
\text { Expert consensus, recommendation } \\
\text { should be considered, benefits depend } \\
\text { on patient situation; benefits and risk } \\
\text { are closely balanced or uncertain }\end{array}$} & $\begin{array}{l}++\mathbf{O} \\
\text { Moderate quality }\end{array}$ & $\begin{array}{l}\text { Observational } \\
\text { studies, trials with } \\
\text { methodological } \\
\text { issues, } \\
\text { inconsistent or } \\
\text { indirect evidence }\end{array}$ \\
\hline & $\begin{array}{l}\text { +OO } \\
\text { Low quality }\end{array}$ & $\begin{array}{l}\text { Case series or } \\
\text { nonsystematic } \\
\text { clinical } \\
\text { observations }\end{array}$ \\
\hline
\end{tabular}

NHMRC levels of evidence

\begin{tabular}{|c|l|}
\hline Grade of recommendation & Description \\
\hline A & Body of evidence can be trusted to guide practice \\
\hline B & $\begin{array}{l}\text { Body of evidence can be trusted to guide practice in } \\
\text { most situations }\end{array}$ \\
\hline C & $\begin{array}{l}\text { Body of evidence provides support for } \\
\text { recommendation(s) but care should be taken in its } \\
\text { application }\end{array}$ \\
\hline D & $\begin{array}{l}\text { Body of evidence is weak and recommendation } \\
\text { must be applied with caution }\end{array}$ \\
\hline
\end{tabular}

This article is protected by copyright. All rights reserved. 
Table 2: Classification of 250HD status

\begin{tabular}{|c|c|c|c|}
\hline $\begin{array}{l}\text { 25OHD } \\
\text { (nmol/L) }\end{array}$ & $\begin{array}{l}\text { ANZ: Children and } \\
\text { adolescents position } \\
\text { paper }(2013)^{2}\end{array}$ & $\begin{array}{l}\text { Global guidelines } \\
(2016)^{1}\end{array}$ & $\begin{array}{l}\text { APEG Working group comment } \\
(2020)\end{array}$ \\
\hline$<12.5$ & Severe deficiency & \multirow[t]{2}{*}{ Deficiency } & \multirow{5}{*}{$\begin{array}{l}\text { Consistent definitions. The global } \\
\text { guidelines combine moderate and } \\
\text { severe deficiency. The working } \\
\text { group recommends the global }\end{array}$} \\
\hline $12.5-29$ & Moderate deficiency & & \\
\hline $30-49$ & Mild deficiency & Insufficiency & \\
\hline 50 & $\geq 50$ : Sufficient & $>50$ : Sufficiency & \\
\hline$>250$ & Elevated & Toxicity & \\
\hline
\end{tabular}

This article is protected by copyright. All rights reserved. 
Table 3: Classification of calcium intake

\begin{tabular}{|c|c|c|c|}
\hline Age group & $\begin{array}{l}\text { ANZ: Children and } \\
\text { adolescents } \\
\text { position paper } \\
(2013)^{2}\end{array}$ & $\begin{array}{l}\text { Global guidelines } \\
(2016)^{1}\end{array}$ & APEG Working group comment (2020) \\
\hline 0-6 months & $\begin{array}{l}\mathrm{Al} \\
200 \mathrm{mg} / \mathrm{d}\end{array}$ & $\begin{array}{l}\mathrm{Al}^{\dagger} \\
200 \mathrm{mg} / \mathrm{d}\end{array}$ & $\begin{array}{l}\text { The APEG working group follows these } \\
\text { recommendations that are identical in both } \\
\text { publications }\end{array}$ \\
\hline 6-12 months & $\begin{array}{l}\mathrm{Al} \\
200 \mathrm{mg} / \mathrm{d}\end{array}$ & $\begin{array}{l}\mathrm{Al} \\
260 \mathrm{mg} / \mathrm{d}\end{array}$ & $\begin{array}{l}\text { The APEG working group follows the global } \\
\text { guidelines recommending higher intake of } \\
260 \mathrm{mg} / \mathrm{d} \text { between } 6-12 \text { months of age }\end{array}$ \\
\hline$>1 \mathrm{yr}$ & $\begin{array}{l}\text { RDA }^{\ddagger} \\
\text { 1-3 yr: } \quad 700 \mathrm{mg} / \mathrm{d} \\
\text { 3-8 yr: } 1000 \mathrm{mg} / \mathrm{d} \\
\text { 9-18 yr: } 1300 \mathrm{mg} / \mathrm{d}\end{array}$ & $\begin{array}{l}\text { Deficiency } \\
<300 \mathrm{mg} / \mathrm{d} \\
\text { Insufficiency } \\
300-500 \mathrm{mg} / \mathrm{d} \\
\text { Sufficiency } \\
>500 \mathrm{mg} / \mathrm{d}\end{array}$ & $\begin{array}{l}\text { There is no specific calcium intake } \\
\text { recommended in the global guidelines, instead } \\
\text { a guide is provided of what is classified as } \\
\text { sufficient or not. } \\
\text { The APEG working group follows the ANZ } \\
\text { guidelines }\end{array}$ \\
\hline $\begin{array}{l}\text { Pregnant/lactating } \\
\text { women }\end{array}$ & $\begin{array}{l}\text { 14-18 yr: } 1000 \mathrm{mg} / \mathrm{d} \\
>18 \mathrm{yr}: \quad 1300 \mathrm{mg} / \mathrm{d}\end{array}$ & N/A & $\begin{array}{l}\text { The APEG working group follows the ANZ } \\
\text { guidelines }\end{array}$ \\
\hline
\end{tabular}

$\dagger$ : Adaequate intake, ‡: Recommended daily allowance

This article is protected by copyright. All rights reserved. 


\begin{tabular}{|c|c|c|c|}
\hline & $\begin{array}{l}\text { ANZ: Children and } \\
\text { adolescents position } \\
\text { paper }(2013)^{2}\end{array}$ & $\begin{array}{l}\text { Global guidelines } \\
(2016)^{1}\end{array}$ & $\begin{array}{l}\text { APEG Working group } \\
\text { comment }(2020)\end{array}$ \\
\hline & \multicolumn{3}{|c|}{ Vitamin D Supplementation } \\
\hline Age group & $\begin{array}{l}250 H D \\
30-49 \mathrm{nmol} / \mathrm{L}\end{array}$ & $\begin{array}{l}\text { Only for the prevention } \\
\text { of nutritional rickets }\end{array}$ & \multirow{11}{*}{$\begin{array}{l}\text { Recommendations of the } \\
\text { global consensus are based on } \\
\text { the presence of nutritional } \\
\text { rickets. } \\
\text { There are no specific doses for } \\
\text { supplementation based on } \\
25 O H D \text { levels like in ANZ } \\
\text { guidelines. } \\
\text { The ANZ paediatric statement } \\
\text { provides specific dosages for } \\
\text { vitamin D insufficiency. } \\
\text { The APEG working group } \\
\text { recommends following the } \\
\text { global guidelines for treatment } \\
\text { and prevention of nutritional } \\
\text { rickets. } \\
\text { For patients with } 25 O H D \text { levels } \\
\text { between } 30-49 \text { nmol/L, } \\
\text { specifically preterm babies } \\
\text { we recommend following the } \\
\text { ANZ paediatric guidelines }\end{array}$} \\
\hline Preterm & $\begin{array}{l}200 \mathrm{IU} / \mathrm{d} \\
\max 400 \mathrm{IU} / \mathrm{d}\end{array}$ & $\begin{array}{l}\text { No specific } \\
\text { recommendation }\end{array}$ & \\
\hline$<3$ months & $<400 \mathrm{lU} / \mathrm{d}$ for $3 \mathrm{mo}$ & $400 \mathrm{IU} / \mathrm{d}$ & \\
\hline 3-12 months & $400 \mathrm{lU} / \mathrm{d}$ for $3 \mathrm{mo}$ & & \\
\hline \multirow[t]{2}{*}{$1-18$ years } & $\begin{array}{l}1000-2000 \mathrm{IU} / \mathrm{d} \text { for } 3 \mathrm{mo} \\
\text { or } 150,000 \mathrm{IU} \text { stat }\end{array}$ & $600 \mathrm{IU} / \mathrm{d}$ & \\
\hline & $\begin{array}{l}25 \mathrm{OHD} \\
<30 \mathrm{nmol} / \mathrm{L}\end{array}$ & $\begin{array}{l}\text { If nutritional rickets } \\
\text { present - spectrum of } \\
\text { vitamin D and/or } \\
\text { calcium deficiency }\end{array}$ & \\
\hline Preterm & $\begin{array}{l}800 \mathrm{IU} / \mathrm{d}, \text { review after } 1 \\
\text { mo }\end{array}$ & $\begin{array}{l}\text { No specific } \\
\text { recommendation }\end{array}$ & \\
\hline$<3$ months & $1000 \mathrm{lU} / \mathrm{d}$ for $3 \mathrm{mo}$ & $\begin{array}{l}2000 \mathrm{IU} / \mathrm{d} \text { for } 90 \mathrm{~d}, \\
\text { single dose not } \\
\text { recommended }\end{array}$ & \\
\hline 3-12 months & $\begin{array}{l}1000 \mathrm{IU} / \mathrm{d} \text { for } 3 \text { mo or } \\
50,000 \mathrm{IU} \text { stat, review } \\
\text { after } 1 \mathrm{mo} \text { and consider } \\
\text { repeat }\end{array}$ & $\begin{array}{l}2000 \mathrm{IU} / \mathrm{d} \text { for } 90 \mathrm{~d} \\
\text { single dose } 50,000 \mathrm{IU}\end{array}$ & \\
\hline \multirow[t]{3}{*}{ 1-18 years } & \multirow{2}{*}{$\begin{array}{l}1000-2000 \mathrm{IU} / \mathrm{d} \text { for } 6 \mathrm{mo}, \\
3000-4000 \mathrm{IU} / \mathrm{d} \text { for } 3 \mathrm{mo} \\
\text { or } \\
\text { single dose } 150,000 \mathrm{IU} \\
\text { and repeat after } 6 \text { weeks }\end{array}$} & $\begin{array}{l}+1 \text { to } 12 \text { yr: } \\
3000-6000 \text { IU for } 90 d \\
\text { single dose } 150,000 \mathrm{IU}\end{array}$ & \\
\hline & & $\begin{array}{l}>12 \mathrm{yr}: \\
6000 \mathrm{IU} / \mathrm{d} \times 90 \mathrm{~d}, \text { single } \\
\text { dose } 300,000 \mathrm{IU}\end{array}$ & \\
\hline & \multicolumn{3}{|l|}{ Maintenance } \\
\hline preterm & $\begin{array}{l}\text { Preterm: } \\
200 \mathrm{IU} / \mathrm{kg} / \mathrm{d} \text {, } \\
\max 400 \mathrm{IU} / \mathrm{d}\end{array}$ & $\begin{array}{l}\text { No preterm } \\
\text { recommendations }\end{array}$ & \multirow{3}{*}{$\begin{array}{l}\text { The APEG working group } \\
\text { recommends following the } \\
\text { ANZ paediatric guidelines for } \\
\text { preterm infants and the global } \\
\text { guidelines for other age groups }\end{array}$} \\
\hline $\begin{array}{l}<3-12 \\
\text { months }\end{array}$ & $400 \mathrm{IU} / \mathrm{d}$ & $400 \mathrm{IU} / \mathrm{d}$ & \\
\hline $1-18$ years & $\begin{array}{l}400 \mathrm{IU} / \mathrm{d} \text { or } \\
150,000 \mathrm{IU} \text { stat at } \\
\text { beginning of autumn }\end{array}$ & $600 \mathrm{IU} / \mathrm{d}$ & \\
\hline
\end{tabular}




\section{University Library}

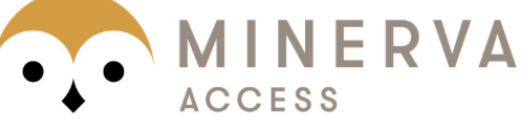

A gateway to Melbourne's research publications

Minerva Access is the Institutional Repository of The University of Melbourne

\section{Author/s:}

Siafarikas, A;Simm, P;Zacharin, M;Jefferies, C;Lafferty, AR;Wheeler, BJ;Tham, E;Brown, J;Biggin, A;Hofman, P;Woodhead, H;Rodda, C;Jensen, D;Brookes, D;Munns, CF

Title:

Global consensus on nutritional rickets: Implications for Australia

Date:

2020-06-01

\section{Citation:}

Siafarikas, A., Simm, P., Zacharin, M., Jefferies, C., Lafferty, A. R., Wheeler, B. J., Tham, E., Brown, J., Biggin, A., Hofman, P., Woodhead, H., Rodda, C., Jensen, D., Brookes, D. \& Munns, C. F. (2020). Global consensus on nutritional rickets: Implications for Australia. JOURNAL OF PAEDIATRICS AND CHILD HEALTH, 56 (6), pp.841-846. https:// doi.org/10.1111/jpc.14941.

Persistent Link:

http://hdl.handle.net/11343/275815 